\title{
ROLE OF THE INDONESIAN NAVY TASK UNIT TO SUPPORTING TECHNOLOGY TRANSFER OF SUBMARINE BY DSME SOUTH KOREA-PT PAL INDONESIA
}

\author{
Nurcahya Dwi Asmoro, Udi Subakti Ciptomulyono, I Nengah Putra A, Ahmadi, Okol Sri Suharyo \\ Indonesia Naval Technology College, STTAL \\ Bumimoro-Morokrembangan Surabaya 60187, Indonesia
}

\begin{abstract}
Indonesian Navy has a strategic project of building three units of submarines in collaboration with DSME South Korea. In the development cooperation submarine contract DSME also include the implementation of Technology Transfer (TT) between South Korea DSME with PT.PAL Indonesia. Therefore necessary strategies to get success TT process submarines. The task force Navy submarine construction that has always worked between DSME and PT.PAL has helped realize the moral burden for the technology transfer program. How Submarine Task Force strategy to ensure the success of PT.PAL accept TT of DSME? SWOT analysis tries to analyze the variables that influence the strategy and product that work discipline, facilities and infrastructure, the relationship between team performance and PT.PAL DSME is a variable that must be maintained and improved. Submarine task force as a motivator can act as a driving force in improving the performance and things - other matters relating to the development of technology over the course of the submarine.
\end{abstract}

Keywords: Submarine, TOT, SWOT.

\section{INTRODUCTION.}

Minimum Essential Force (MEF) began to be implemented during the administration of President of the Republic of Indonesia (RI) Susilo Bambang Yudhoyono. MEF program execution starts with a budget increase by the MoD (Ministry of Defense). The increase in the budget devoted to military flatform update and improve the functions and authorities of the Ministry of Defense. It is as a means to improve the professionalism of soldiers. MEF for the Indonesian Navy (TNI AL) is a standard for establishing minimum force posture Navy. Navy posture is taken into account to carry out the duties and functions of the Navy well. Naval force posture that can improve deterrence effect for the threat of another country's navy (Haryanto, 2017).

MEF on this year is in the second phase (2015-2019) with the implementation of the development to proceed on the results achieved in the first phase MEF (2010-2014), MEF phase II (2015-2019) and MEF phase III (2020 - 2024) carried out by observing the development of the strategic environment. Environmental development strategy of a regional and global region. The development of a new threat around Indonesia, a change in the balance of power, conflicts occur because of violations of territorial sovereignty by other countries of Indonesia and the theft of Indonesia's natural resources, as well as the cooperation of handling transnational crime and natural disasters (Podberezkin, 2017).

A policy of the Indonesian government raised the maritime sector as the potential to improve the national economy should be supported by the development of maritime forces of a powerful and respected in the region. Maritime force development is not only intended to safeguard the sovereignty and protecting the natural resource 
wealth of maritime Indonesia but also aimed at establishing maritime security and safety of navigation (Marsetio, 2017), This condition requires a strong defense posture so as to protect the territorial integrity and able to be driven up to the EEZ covers regional and global to the Indian Ocean and the Pacific.

Development of defense posture that has the strength and ability of the above, it should be supported by an independent defense industry so as to create a domestic defense equipment and eliminate dependence on foreign defense equipment (Sitnikov, 2016), It can be concluded that the defense industry is part of the defense system in which development of the defense industry is also a defense development.

The national defence industry is an industry that consists of state-owned enterprises and private property, whether working alone or in groups to produce defence equipment and maintenance services for the security and strategic interests (Zaitsev, 2017), Development of the defence industry will also provide a multiplier effect, namely technology and the economic effect. In the sense in addition to increasing the ability of defence technology is also able to improve the national economy (Sitnikov, 2016),

Because defence industry engaged in the production requirements for defense equipment and security and maintenance, the development of the defense industry self-reliance will be able to raise the deterrent effect (deterrent effect) for Indonesia. Especially when the defense industry producing the main weaponry system (defense equipment) that have strategic value (Gray, 2003), Such as the construction of submarines by PT.PAL.

To realize the independence of the defense industry, one way is to carry out the procurement process that includes Technology Transfer (TT) or the transfer of technology from the producer to the Indonesian defense industry designated by the government (Blalock \& Gertler, 2008), As well as the procurement of submarines from South Korea, PT.PAL defence industry as designated by the Indonesian government has sent experts shipbuilding and engineering to carry out the process TT (Harden \& Davies, 2016). Experts are trained to Daewoo Shipbuilding and Marine Engineering (DSME) in Okpo South Korea. The learning process starts from the basic design to the construction, which is expected to experts Indonesia is able to absorb and master the technology of submarine construction. Thus the construction of the 3rd submarines held in PT.PAL can run well under the conditions expected.

The seriousness of the government in the development of the defence industry aims to be able to realize the independence of defence equipment through ToT process as it has been implemented in the procurement of submarines between Indonesia - South Korea. TT process is expected to encourage PT.PAL be a defence industry that is capable of producing submarines in the future. From this background, the formulation of the problem to be discussed is "How Strategy to support technology transfer and how the role of submarine Submarine Task Force to speed up the process of technology transfer from DSME to PT.PAL in the construction of a submarine?"

Furthermore, from this study are expected to be determined a strategy to accelerate mastery of submarine construction technology as a result of the cooperation procuring submarines from South Korea. Thus the strategy can realize PT.PAL as domestic maritime defence industry that is capable of self-sufficient in producing submarines in order to achieve the appropriate strength MEF.

\section{MATERIALS AND METHODS}

\section{a. Research Accomplished}

There are several methods that can be used in the planning or formulation of 
industry or enterprise development strategy. From the previous study researchers found and used as the reference method are:

\section{A SWOT Analysis Of Collaborative} Strategies Between Engineering Universities And Industry In Pakistan (Rashidi \& Zaki, 2014), This study contains Cooperation between academia and industry in every country has a long-term vision to promote commercial product innovation. in practice, this requires an in-depth analysis of to reveal important aspects of a well-informed decision making. The aim of this research is to analyze the SWOT (Strengths, Weaknesses, Opportunities, and Threats) from cooperation in education, research, and practice. this study Identifies the strengths and weaknesses of the existing cooperation strategies; opportunities to build good and beneficial relationships, and threats that could hinder the development of planned programs. developed programs are then created practical schemes to build productive relationships between two partners through creative leadership, effective strategic partnerships, and systematic operating models to advance with implications for academia, researchers, and industry. This research is qualitative, using interpretive approach. Data collection using semistructured group and discussions from industry experts and Academics; the Primary Data Obtained were Analyzed using thematic analysis through open and axial coding. The study Identifies obstacles to collaborative efforts and describes the role of industry and academia to Overcome Reviews These barriers along with the SWOT matrix.

The Strategy of Social and
Economic Regional Development
Territorial Brand Building (Panacheva \&

Popil, 2016), This article uses regional brands, and the brand has gained popularity in economics and politics, as regional missions and regional development strategies, territorial brand algorithms are offered, similarities and differences with the branding of goods or services. The authors Analyzed the structure of the program document - "Strategic social and economic development of the region" as a source of information for building a territorial brand. For example, identify a number of strategic development area programs with information about step and SWOT analysis. The author analyzes the Strategic relationships with regional brand indicators, Russian territorial missions, Reviews their formulations and the availability of "core" in the mission. An analysis of the existence of other factors that influence the possibility of establishing a territorial brand in the region. The authors highlight part of the Strategy, the which can serve as a source of information in the territorial branding process, as well as the new Strategy concept content with the "Regional Brands" section offered.

Strategic Planning for Port Development: Improvement of Container Transit from the Iranian Southern Ports Terminals (Yousefi, 2103), The researcher seeks to provide that the formulation of a port in southern Iran's development strategy is crucial to plan. Port development should be Able to be used for container transits with a minimum of resources such as server capacity, human resources, and financial potential to expand container transit port in developed areas. but the formulation of strategic objectives within the business strategy will be implemented an after the vision and mission of the port are the agreed 
upon. in order to improve the results of port management operations, it is advisable to focus on new strategies such as the exploitation of transit corridors for the development of the port in southern Iran. The main part of this study was used to Evaluate the role of container transport from the southern port terminals of Iran from various transportation Routes to Increase the number and quality of Maritime Transport in Iran. The need for an existing competitor's of data collection to construct a potential defence strategy in the Persian Gulf and to calculate the comparison between Reviews their strengths and weaknesses and their strength is of utmost importance. Therefore, careful analysis of the harbour environment needs to be done. Once the competition and the port have been Analyzed environment, it is possible to begin construction of a SWOT analysis for Container Terminals in the Southern part of Iran that has a strategic position and Allows as a transit base in the region. Therefore,

\section{b. Theoretical basis}

The Defense Mission is to prepare a military army that can be superior and reliable to win the war, Prevent war and protect the security of our nation (Mattis, 2018), Thus, defense Indonesian state is to protect the people and the country of Indonesia, promote the general welfare, educating the nation and participate in the establishment of world order. State defence is also an attempt to defend the country's sovereignty, territorial integrity and safety of the entire nation from threats and harassment.

Soldiers are one of the institutions that are present in everyday life in the environment of a society or country. A prominent sociologist David Segal has the notion that "one can not read a newspaper without Realizing the impact army has had." This suggestion shows that the figure of the army covers a wider area, in reality, referring to all institutions that legitimately use force and through the control of the modern state, the which consists of the army, the navy and the air. Special Forces Command, intelligence units. the existence of military organization in modern society is a permanent institution. Army institutions have the objective of managing violence/conflict in a country, running a monopoly of violence received by Civilians even in the most liberal communities (Sofronea, 2016).

Generally, the defence industry has production results linked to military equipment and defence policy under defence orders and programs of a country (Brovko \& Petruk, 2016), For defence equipment and security, are all tools and equipment to support the country's defence and security and public order.

A committee formed under President Susilo Bambang Yudhoyono that Defense Industry Policy Committee (KKIP) has a function as a national policy coordinator for planning, formulating, implementing, controlling, synchronizing and evaluating all matters relating to the defence industry.

In the management of the country's defence system also needed a government policy that regulates how the state defence system will be implemented. This policy as a reference in the planning, implementation and supervision of the national defence system. With some of the main points of the policy is the implementation of the development of an integrated national defence system consisting of military and 
non-military defence to be synergies and to increase effectiveness and efficiency in the coordination of the national defence. Efforts are underway to develop the technology is by way of research and development and technology transfer. Technology Transfer is known as one the fastest and precise and fastest method for the country and companies to increase of the pace of development of Reviews their industry,

Three main components that directly affect the activities Technology Transfer, namely (Shafia \& Shakeri, 2010):

1. Own technology, which is also called the Transferor and ready to deliver technology or to share with others,

2. Recipient, buyers technology referred to as Technology transferee, and

3. Linkages a channel for the transfer of technology.

TT process has unique characteristics and different from the others because it contains activities that have specific characteristics of each, so that the uniqueness and specificity should be considered as a single project. Therefore, in the process of technology transfer, there are four methods used, namely methods: passive or active, collaborative, competitive and general methods (Shafia \& Shakeri, 2010).

This study aimed to establish a conceptual framework that can target buyers receive a transfer of technology in the technology program by the sellers of technology. Thus be described any important elements in the transfer process, and to address the possibility/of the current weakness, using a concept study/means to raise the level of collateral the TT.

\section{c. Research Methods}

This study uses Mixed Methods Research (MMR) is a combined approach of qualitative descriptive literature or also popularly known as the bibliographical research with quantitative Strength Weakness Opportunities and Threats (SWOT). Secondary data is needed to fully rely on theoretical data and document library. While the primary data from field studies rely on data informants/respondents related to the subject of research. To determine the respondents used the purposive sampling technique to prepare in advance the target respondents but in its development can be replaced. The respondents were senior officers involved in the submarine unit as the procurement task force new submarines cooperation Indonesia - South Korea.

\section{ANALYSIS AND DISCUSSION.}

\section{a. Research variable}

1) TT program. TT program or transfer of technologies launched by the government on every purchase of defence equipment from abroad is an opportunity for the defence industry to lead to the independence era of defence equipment. Similarly, the procurement of submarines cooperation agreement between South Korea and Indonesia provides an opportunity for PT. PAL as one of the strategic defence industry to meet the needs of the Navy defence equipment, including the development of domestic submarines. The success of the construction of the submarine by PT. PAL will prove that Indonesia is able to accept the transfer of technology well (Condro, 2017), The success of technology transfer will increase the capabilities of the defence 
industry and is able to support the balance of power in the region.

Mastery of submarine technology is very necessary for consideration of the high strategic value of submarines in a state of defence. For that, we need a proper strategy in the procurement/purchase of submarines from abroad. The strategy in addition to the ability of Indonesia to buy are also required to be able to master the technology (Condro, 2017), This can be done by agreement between the Indonesian TT as the buyer country with South Korea as the country of production.

By having a submarine technology then Indonesia will align with state authorities submarine technology such as Germany, Russia, USA, France, China and Turkey (Herz, et al., 2017), Given the presence of the submarine can provide high deterrent effect the mastery of submarine technology and defense industry will boost the progress of the national authority in the region.

\section{2) Selection of qualified human} resources. Human resource is the principal component that ensures the success of a company (Gauche, et al., 2017), Superior human resources would be easy to improve the mastery of ToT process. During the manufacturing process submarines 1 st and 2nd in South Korea, several times carried PT.PAL delivery personnel in order to improve the capability of Human Resources in the development process submarines.

Another attempt to prepare PT.PAL human resources is to carry out the selection in the fulfilment of the required amount of personnel, expertise by taking power from the personnel as well as the selection of structural PT.PAL outside with appropriate considerations of efficiency and effectiveness required expertise and adequate work experience. Human resources force of this section with a selection taken from personnel who have experience in other universities.

It also conducted recruitment expert submarine structure of the Faculty of Naval Architecture and experts ITS weaponry systems and electronic fields of PENS-ITS.

To enhance its ability human resources PT.PAL also includes personnel in the activities of 209 class submarine overhaul, namely KRI KRI CKA-401 and NGL-402 which will soon be implemented.

3) Construction of facilities, infrastructure and facilities. Development of infrastructure construction investment in several countries proved to be effective, efficient and reliable as a means to stimulate economic growth in the country (Zhelezniak, 2017), Therefore, construction of facilities, infrastructure is the subject matter that should be implemented to support the construction of a submarine in the shipyard PT.PAL.

4) Research and development. To improve the ability PT.PAL in development and production defence armament carried out cooperation in the field of research and development with the LHI-BPPT, colleges of technology such as ITS, and Ministry of research and technology, Higher Education and Research and the Ministry of Defense.

This needs to be carried out considering a technology that is dynamic, constantly changing times. Technological development, especially in the field of defence equipment is an improvement to the nation's defence capability (Ehsani, et al., 2017),

5) Continued Cooperation with South Korean DSME. To face all difficulties to be 
faced in the future in terms of the development of domestic submarines, PT.PAL assembling a team cooperation will continue to liaise with the South Korean DSME. This cooperation will continue to be implemented until the process is complete ToT.

6) Cooperation with the Consultant. This collaboration is focused on infrastructure development planning and preparation of human resources needs adjusted between capability and number of each - each field is required (Weinberger, 1998),

7) Area sea to sea trial or Sea Acceptance Test (SAT). Sea trial and the final inspection is indispensable for any activity that completed construction vessel so that it can be tested to assess that the vessel is in conformity with the standards required by the customer. Contractors as the implementer of the ship will propose agenda sea trial and schedule test activities for all systems that work in the ship could be tested properly and gradually (Navysea, 2017),

To meet the needs of sea trial for submarines being built in PT.PAL, as contractor then will draw up a schedule of activities PT.PAL sea trial or SAT. For the implementation of this activity takes marine areas to have special characteristics because of having submarines have different criteria from the boat on the water. Therefore we need an area of sea trial / SAT which can accommodate all trial activities for submarines, ranging from the surface's manoeuvring to underwater's maneuvring.

PT.PAL as the contractor in the implementation of submarine construction in cooperation with South Korea, until now has not had a workout area/sea trial / SAT for new submarines. Navy as a user can make a proposal to the PT. PAL in determining suitable areas for sea trials the submarine.

\section{b. Step Strategy Formulation}

1) SWOT Matrix Analysis. SWOT matrix is a tool for managers in the process of strategy through four types of strategies, namely SO Strategy (strengths opportunities), WO Strategy (drawback - the odds), Strategy ST (strength - the threat) and WT Strategy (drawback - the threat). Placement of variables - variables that affect the strategy obtained by questionnaire to the respondents' experts, so that a variable which can be categorized as the strengths, weaknesses, opportunities and threats, all of which is an assessment of the expert. This can be arranged after the questionnaire is executed (Padash, et al., 2106),

Of the four strategies are then developed into the expected output strategy. SWOT analysis can be seen in Table 1 .

Table 1. SWOT Matrix Analysis

\begin{tabular}{|c|c|c|}
\hline $\begin{array}{l}\text { internal } \\
\text { external }\end{array}$ & $\begin{array}{l}\text { Power: } \\
\text { 1.Dicipline of human } \\
\text { resources PT PAL } \\
\text { 2.infrastructure }\end{array}$ & $\begin{array}{l}\text { Weakness: } \\
\text { 1.Area SAT } \\
\text { 2.Quolity of human } \\
\text { resources PT PAL } \\
\text { 3.management } \\
\text { 4.Availability of } \\
\text { Submarine Spare Parts } \\
\text { 5.design capability }\end{array}$ \\
\hline $\begin{array}{l}\text { opportunities: } \\
\text { 1.teamwork relationship DSME-PT PAL } \\
\text { 2.quolity of human resources DSME } \\
\text { 3.DSME sufficient human resources in } \\
\text { all areas } \\
\text { 4. PT PAL research and development } \\
\text { cooperation with others } \\
\text { 5.supervision by defense industry policy } \\
\text { committee (KKIP) }\end{array}$ & SO strategy & W0 strategy \\
\hline $\begin{array}{l}\text { Threat: } \\
\text { 1. target failure on the TT }\end{array}$ & ST strategy & WT strategy \\
\hline
\end{tabular}

2) Analysis of Internal Factor Evaluation (IFE). Used to summarize the variables - variables from within that will affect the decision-making and strategy as well as be evaluating the variables - these 
variables to then categorize into variable strengths and weaknesses. The numbers the numbers in the column The rating is an assessment of respondents' interest in any aspect of the existing variables in the questionnaire. This figure includes interest where the value of 1 (not important), the second (bit / somewhat important), a value of 3 (important) and 4 (absolutely / very important). While the weight value is the ratio of the total weight of each variable with the total weight of the whole. As an indicator of the truth of weight calculation can be seen that the total sum of the weights is the number 1 (one).

Table 2. Analysis IFE

\begin{tabular}{|l|c|c|c|}
\hline \multicolumn{1}{|c|}{ Power } & rating & Weight & Score \\
\hline $\begin{array}{l}\text { The level of discipline } \\
\text { the employee/human } \\
\text { resources PT.PAL }\end{array}$ & 2.5 & 0.24 & 0.6 \\
\hline $\begin{array}{l}\text { The readiness of } \\
\text { facilities and } \\
\text { infrastructure in the } \\
\text { submarine } \\
\text { construction process }\end{array}$ & 4.0 & 0.26 & 1.04 \\
\hline & & $\mathbf{0 . 5}$ & 1.64 \\
\hline Weakness & 3.5 & 0.11 & 0.39 \\
\hline $\begin{array}{l}\text { Not yet available area } \\
\text { Sea Acceptance Test } \\
\text { (SAT) for the new } \\
\text { submarines }\end{array}$ & & 0.10 & 0.30 \\
\hline $\begin{array}{l}\text { The quality of human } \\
\text { resources of } \\
\text { specialized } \\
\text { knowledge submarine }\end{array}$ & 3.0 & 0.11 & 0.28 \\
\hline $\begin{array}{l}\text { Management/division } \\
\text { of labour }\end{array}$ & 2.5 & $\mathbf{1}$ & $\mathbf{3 . 1 4}$ \\
\hline $\begin{array}{l}\text { The ability of supply } \\
\text { of spare parts in the } \\
\text { future submarine }\end{array}$ & 2.5 & 0.10 & 0.25 \\
\hline $\begin{array}{l}\text { Human resource } \\
\text { capabilities in } \\
\text { submarine design } \\
\text { independently }\end{array}$ & 3.5 & 0.08 & 0.28 \\
\hline & & $\mathbf{0 . 5}$ & \\
\hline Total IFE & & & \\
\hline
\end{tabular}

\section{3) Analysis of External Factor}

Evaluation (EFE). To summarize the variables - variables from the outside that will affect the decision-making and strategy as well as evaluate the variables - variables that exist and identify opportunities become variable and variable threats. Determining the value rating and the weight value when determining the value equal to the rating and weighting on the analysis of the IFE.

Table 3. Analysis EFE

\begin{tabular}{|l|c|c|c|}
\hline \multicolumn{1}{|c|}{ Chance } & rating & Weight & Score \\
\hline $\begin{array}{l}\text { Relations/cohesiveness of } \\
\text { the DSME team teamwork } \\
\text { PT.PAL }\end{array}$ & 2.0 & 0.10 & 0.20 \\
\hline $\begin{array}{l}\text { The quality of human } \\
\text { resources DSME team }\end{array}$ & 3.0 & 0.11 & 0.33 \\
\hline $\begin{array}{l}\text { DSME team of personnel } \\
\text { to cover all areas of ship } \\
\text { development }\end{array}$ & 2.0 & 0.09 & 0.18 \\
\hline $\begin{array}{l}\text { R \& D cooperation } \\
\text { between PT.PAL with } \\
\text { other parties }\end{array}$ & 3.5 & 0.09 & 0.32 \\
\hline $\begin{array}{l}\text { Supervision of KKIP } \\
\text { against submarine } \\
\text { construction process }\end{array}$ & 3.0 & 0.11 & 0.33 \\
\hline & & $\mathbf{0 . 5}$ & $\mathbf{1 . 3 6}$ \\
\hline Threat & 2.5 & 0.5 & 1.25 \\
\hline $\begin{array}{l}\text { Failure to achieve the } \\
\text { target on the } \\
\text { implementation of the ToT }\end{array}$ & & $\mathbf{0 . 5}$ & $\mathbf{1 . 2 5}$ \\
\hline & & $\mathbf{1}$ & $\mathbf{2 . 6 1}$ \\
\hline Total EFE & & \\
\hline
\end{tabular}

4) SPACE matrix analysis. SPACE matrix is an acronym for Strategic Position and Action Evaluation which is used to evaluate the strategic position. SPACE matrix analysis to generate a certain position for the most appropriate strategies that can be taken and applied for a management company. This matrix is the development of a matrix of Boston Consulting Group (BCG).

SPACE matrix displays four quadrants to determine the strategic position that will be formulated based on the score weighting IFE and EFE weighted score to get a point on which the position of the strategy can be placed. Its application is by comparing the difference in the IFE variables ie number of rated power minus weaknesses (1.64 to 1.5 ) to obtain a positive value of 0.14 (located on the right axis) and the calculation of the difference in the value of the variable EFE 
value reduced opportunities threat value (1.36 to 1.25), which produces a positive number is worth 0.11 (located above the shaft). Furthermore, the figures - the figure is if the plot into SPACE Matrix as shown in the figure below.

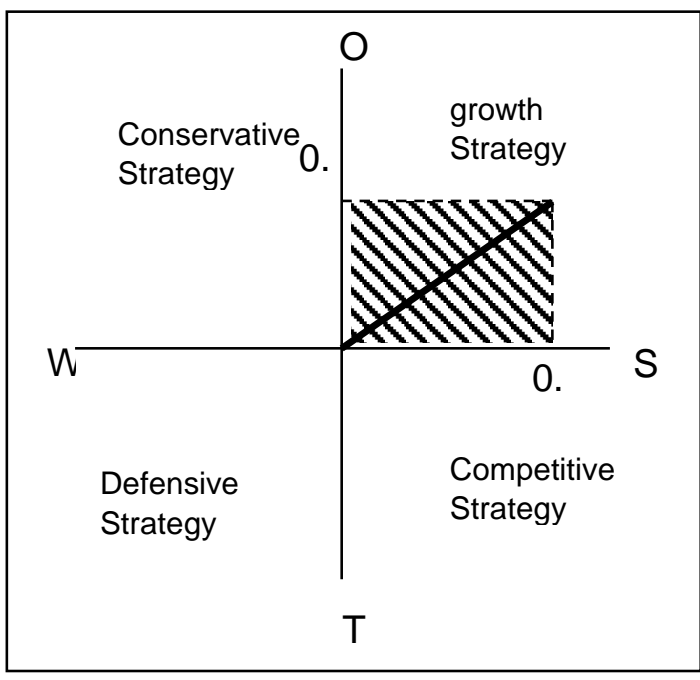

Fig. 1 Matrix SPACE

\section{CONCLUSION}

\section{a. Strategies to Support Technology}

\section{Transfer Process}

Indicators of a successful defense industry can be seen from the increase in production which are used by users of both the military and the orders of the military abroad, increasing professionalism and human resource capacity of the defense industry, and the more complete facilities and infrastructures are owned in order to carry out production, From this research has then be formulated strategy to accelerate the process of submarine construction technology transfer as follows:

The level of discipline and team spirit PT.PAL involved in the construction of the submarine is good enough, should this condition be maintained and continuously improved. As the development of human resources should also their inventory of completeness of facilities and major infrastructure, which in its current condition is sufficient but this does not mean that as an indicator of the cessation of innovation, but need to look for infrastructure other assistive true-absolutely necessary in the implementation of submarine construction and not owned by PT. PAL submarine Division.

Han association and cooperation between the team and the team PT.PAL DSME and the availability of quality human resources DSME good team with a background of more experience should be used to absorb as much specialized knowledge in the field of submarine engineering, by a team of PT.PAL. Similarly, the position of the DSME team where a sufficient number of personnel to cover all parts of the submarine construction system can be used to acquire/absorb a more complete experience as the submarine capital further development independently.

Unavailability of the area to carry out the SAT should be a serious concern in view of the determination of the appropriate sea area for the submarine need for research and a survey of ocean characteristics are best suited for the experimental submarine. Besides the cooperation in the field of research and development ( $R$ \& D) between PT PAL with the private $R$ \& $D$ and higher education is a gateway that is optimistic to develop submarine technology in the future, so that the independence of defence equipment, especially submarines have a good future.

Another variable that encourages to further boost the performance PT.PAL is their inherent supervision of KKIP. This should serve as a partner to provide input - input 
correction for the sake of perfection PT.PAL submarine construction nationwide.

Variables - variables when synergized well above can overcome the threat of failure in the process of technology transfer. Thus the success of the technology transfer process can be realized more real, in order to meet the needs of defence equipment in accordance MEF and independence of the nation in the field of defence industry.

b. The role of the Task Force Navy Submarine In Support of Technology Transfer Process

Moral burden attached to Task Force

Navy Submarine to the success of technology transfer is quite an effect, and not only by the personnel of the task force but also by all personnel Brevet Sharks Kencana. For it as a manifestation of what is a moral burden, we encourage and expect the Task Team Navy's submarines in the submarine construction in PT.PAL, able to be a driving force to improve the work discipline of PT.PAL team and always provide us with feedback to the PT.PAL the infrastructure that needs to be completed, including proposals for marine areas for the implementation of the SAT.

In addition the Task Force submarine that stands between the team and the team DSME PT.PAL able to be an intermediary in maintaining good relations and cooperation and as an arbiter in deciding problems faced between PT.PAL and DSME.

To improve the technology acquired as a result of the transfer of technology over the years, the Task Force submarines can provide us with feedback to PT.PAL to establish cooperation in the field of research and development of submarine technology to enhance all the existing shortcomings. They also provide advice and input to PT.PAL KKIP on submarine construction phases that will be undertaken in order to be completed on time according to the schedule agreed work plan, and give feedback on existing problems in order to avoid delays in the construction of submarines.

\section{5. BIBLIOGRAPHY.}

Blalock, G. \& Gertler, P. J., 2008. Welfare Gains from Foreign Direct Investment Through Technology Transfer to local suppliers. Journal of International Economics, LXXIV(2), pp. 402-421.

Brovko, P. M. \& Petruk, G. V., 2016. Strategic Management of Development of the MilitaryIndustrial Complex Enterprises with the use of Dual Technologies Under the Resource-Based Approach. Economic and Sosial Changes: Facts, Trends, Forecast, III(45), pp. 82-97.

Condro, H. S., 2017. Strategy to Improve Naval Shipbuilding Industry Self-Reliance in Indonesia. Monterey, California: Naval Post Graduate.

Ehsani, V., Azami, M., Najafi, S. M. B. \& Soheili, F., 2017. The Effectivenness of Domestic Scientific Research on Iran Development Indicators. Iranian Journal of Information Processing and Management , XXXII(2), pp. 319-347.

Gauche, C., Beer, L. T. d. \& Brink, L., 2017. Managing Employee Well-Being: A Qualitative Study Exploring Job and Personal Resources of atrisk Employees. South African Journal of Human Resource Management, XV(0), pp. e1-e13. 
Gray, C. S., 2003. Maintaining Effective Deterrence. 1 penyunt. Berkshire, England: University of Reading.

Harden, H. \& Davies, 2016. Marine Science and Technology Transfer : Can the Intergovermental Oceanographic Commission Advance Governance of Biodiversity Beyond National Jurisdiction?. Marine Policy, Volume LXXIV, pp. 260-267.

Haryanto, J. T., 2017. Potential Impact of Fulfilment of Minimum Essential Force (MEF) to The Regional Welfare. Jurnal Ekonomi Kuantitatif Terapan, X(2), pp. 27-37.

Herz, M., Dawood, L. \& Lage, V. C., 2017. A Nuclear Submarine in the South Atlantik: The Framing of Threats and Deterrence. Contexto International, XXXIX(2), pp. 329-350.

Marsetio, 2017. Indonesian Sea Power and Regional Maritime Security Challenges. JMSNI Journal of Maritime Studies and National Integration, I(1), pp. 34-46.

Mattis, J., 2018. 2018 National Defense Strategy of The United States of America. Arlington County, Virginia: Department of Defense United States of America.

Navysea, 2017. Trial and Delivery of Ships Bought for Foreign Military Sales (FMS). wahington: Commander Naval Sea System Command.

Padash, A., Jozi, S., Nabavi, S. \& Dehzad, B., 2106. Stepwise Strategic Environmental Management in Marine Protected Area. Global Journal of Environmental Science and Management, II(1), pp. 49-60.
Panacheva, A. S. \& Popil, V. A., 2016. The Strategy of Social and Economic Regional Development Territorial Brand Building. Nauka Krasnoara, Issue 6, pp. 57-69.

Podberezkin, A. L., 2017. Call For A New National Security Strategy: Governing The Future Instead of Deterring It. Vestnik, LII(1), pp. 1-20.

Rashidi, Z. \& Zaki, S., 2014. A SWOT Analysis of Collaborative Strategis between Enggineering Universities and Industry in Pakistan. Mehran University Research Journal of Enggineering and Technology, XXXIII(4), pp. 461-470.

Shafia, M. A. \& Shakeri, A., 2010. Introducing a Project Management Framework for Transfer of Technologies. International Journal of Industrial Engineering \& Production Research, XX(4), pp. 177-185.

Sitnikov, S., 2016. Assessment of Efficiency of Investments Into The Enterprises of Defense Industry Complex. Modernizacia Innovacia Razvitie, VII(1), pp. 34-40.

Sofronea, O., 2016. The Civil Democratic Control on the Army Forces in Romania 1989 - 2007. South East European journal of Political Science, IV(2), pp. 27-49.

Weinberger, L. A., 1998. Commonly Held Theories of Human Resource Development. Action Learning: Research and Practice, I(1), pp. 75-93.

Yousefi, H., 2103. Strategic Planning for Port Development: Improvement of Container Transit from The Iranian Southern Ports Terminals. 
TransNav: International Journal in Marine Navigation and Safety of Sea Transportation, VII(3), pp. 433-440.

Zaitsev, M., 2017. Military Strategy Of India. Vestnik MGIMO Universiteta, LIII(2), pp. 52-70.
Zhelezniak, V., 2017. Economic and Legal Grounds for Investment in Development of Transport Infrastructure. Nauka ta Progres Transportu, LXVII(2), pp. 27-33. 